\title{
Article \\ Advancing the Evangelical Mind: Melvin Grove Kyle, J. Gresham Machen, and the League of Evangelical Students
}

\author{
Jeffrey S. McDonald 1,2 \\ $1 \quad$ Sioux Falls Seminary, Sioux Falls, SD 57105, USA; jsmcdonald47@gmail.com \\ 2 Avery Presbyterian Church (EPC), Bellevue, NE 68005, USA
}

check for updates

Citation: McDonald, Jeffrey S.. 2021. Advancing the Evangelical Mind: Melvin Grove Kyle, J. Gresham Machen, and the League of Evangelical Students. Religions 12: 498. https://doi.org/10.3390/ rel12070498

Academic Editors: Antony W. Alumkal, Randall Balmer and Edward Blum

Received: 7 June 2021

Accepted: 29 June 2021

Published: 4 July 2021

Publisher's Note: MDPI stays neutral with regard to jurisdictional claims in published maps and institutional affiliations.

Copyright: (C) 2021 by the author. Licensee MDPI, Basel, Switzerland. This article is an open access article distributed under the terms and conditions of the Creative Commons Attribution (CC BY) license (https:// creativecommons.org/licenses/by/ $4.0 /)$.

\begin{abstract}
This article seeks to analyze Melvin Grove Kyle and the growth of the League of Evangelical Students (LES) founded by J. Gresham Machen and Princeton Seminary students in 1925. Both Kyle and Machen were scholarly leaders in the LES and served on the organization's board together. This paper will establish the importance of Melvin Grove Kyle as a leading evangelical scholar and biblical archaeologist. It will also explain the origins and growth of the LES and how various Presbyterians influenced the organization and sought to advance a broader evangelical Protestant intellectual life in the difficult period of the 1920s and 1930s. Machen's role will be highlighted, and the thinking of various evangelical scholars associated with the LES will be analyzed. This study is important because it helps us grasp how evangelical Protestantism rehabilitated and advanced itself intellectually in a period when the movement faced educational marginalization in the wider culture.
\end{abstract}

Keywords: League of Evangelical Students; Melvin Grove Kyle; James Orr; J. Gresham Machen; Xenia Seminary; Princeton Seminary

\section{Introduction}

In 1925, when J. Gresham Machen and his Princeton Seminary colleagues were launching the League of Evangelical Students (LES), no Presbyterian Church U.S.A. seminary presidents came to their aid. However, the president of the nation's oldest and most enthusiastically evangelical Presbyterian seminary, Xenia, decided to support Machen and the LES from the start. Xenia was founded in 1794 and was one of two United Presbyterian seminaries in America. The United Presbyterian Church of North America was a merger of groups that came out of the 17th century Scottish Covenanters and the 18th century Scottish Seceder movement. The UPCNA, whose members were identified as UPs, were an evangelical Presbyterian denomination with a populist orientation. Moreover, the UPCNA was a much smaller denomination when compared to the larger mainline PCUSA. While other Presbyterian seminary administrator's spurned Machen's efforts the spirited United Presbyterian, Melvin Grove Kyle, embraced them wholeheartedly. Tall and rail thin the sixty-seven-year-old Kyle was a biblical archaeologist and an advocate of evangelical Presbyterian scholarship and the bold stands of Machen. Kyle, who was perhaps the most scholarly Presbyterian seminary president in America, was a volcano of energy and there was no doubt where he stood in the great theological debates of his era. Kyle wrote several books, edited a leading Christian academic journal, participated in many excavations, taught and lectured on biblical archaeology widely, established a Bible lands museum that still exists today, and belonged to various academic societies. He was learned and diplomatic, but unwavering in his theological stance and his commitment to evangelical Presbyterian scholarship. Indeed, Kyle and others from the UP tradition wrote articles in The Fundamentals (1910-1915), the famed paperback volumes devoted to presenting Christian truth. Kyle's career as a biblical archaeologist and his efforts with the distinguished evangelical scholar J. Gresham Machen to lead the fledging League of Evangelical Students reveals a significant, but largely unnoticed dimension of evangelical history. This study is important because it helps us grasp how evangelical Protestantism 
rehabilitated and advanced itself intellectually in a period when the movement faced educational marginalization in the wider culture. The fact that so many of evangelicalism's most prominent scholars emerged from the LES reveal a vital, but largely overlooked way in which evangelical minds were formed and evangelical scholarship expanded. The UP tradition, as exemplified by Kyle, combined with the efforts of Machen and the professors of Old Princeton in the LES reveal an important way evangelical scholarship organized itself and moved forward in the critical period of the 1920s and 1930s. The scholarly efforts of Kyle and Machen and the growth of the League of the Evangelical students in the 1920s and 1930s were indeed critical to the rise of evangelicalism in mid twentieth century America and beyond. Conservative and moderate evangelicals and fundamentalists were influenced by the organization. While various evangelical Protestants were involved in the LES the different Presbyterian influences on the organization were most prominent. Kyle, Machen, and the LES challenged evangelicals to take the life of the mind seriously. Their work laid the foundation for a resurgent evangelicalism that was increasingly intellectually engaged.

\section{Kyle's Early Life and Education}

Melvin Grove Kyle was born on 7 May 1858, on a farm in Harrison County, Ohio, a rural and sparsely populated area in the eastern part of the state. Kyle was from Scots-Irish and German descent and raised in the United Presbyterian Church of North America (Leonard 1908, p. 418). In 1881 he graduated from the UP's Muskingum College in New Concord, Ohio. Retrospectively, Kyle claimed that Muskingum was at the time "one of the most conservative [Christian] institutions in the land (Kyle 1932, p. 26)." Nevertheless, Kyle claimed that he and his Muskingum students spent lots of time at the college discussing skepticism and liberal ideas. Kyle argued that they did this so much that he and his fellow classmates "must have seemed to our betters an unbelieving lot." According to Kyle he talked to his father and minister about the new ideas. Kyle noted:

When we returned occasionally to our homes, we began to air some of our sophomoric wisdom and our fathers peered over their glasses at us and said, "Tut, tut". And we "tutted"! Then perhaps we spoke to our old pastor about our intellectual qualms and he said sympathetically, remembering his own student days, "Oh well, after a while, these ideas will not trouble you so much". He knew they were only growing pains. So we subsided (Kyle 1932, p. 26).

Based on the evidence it appears that whatever intellectual issues troubled Kyle, he appeared to resolve them. His questioning in college, as he said, "subsided" and he pursued further education at Muskingum and in the United Presbyterian's Xenia Seminary in Xenia, Ohio. However, after two years of study at Xenia, Kyle, transferred to the other United Presbyterian seminary, Allegheny, on the north side of Pittsburgh. The reason for the transfer is unclear. In 1884 he earned an M.A. from Muskingum and in 1885 Kyle graduated from Allegheny. He was licensed to preach by the UPCNA in 1885, but he did not enter ministry immediately (Gilliland 2008, pp. 285-86). He returned to Xenia for a further year of post graduate study. Xenia in the 1880s was known for its commitment to the fundamentals of the faith and Xenia did have some scholars with substance. For instance, Xenia's apologetics professor, David McDill, was a specialist in seeking to refute liberal Old Testament criticism and he wrote widely on the subject and this emphasis appears to have influenced Kyle. In seminary education the United Presbyterians were taking an evangelical scholarly path and Xenia's stamp was firmly imprinted on Kyle's mind and life.

Kyle was ordained in May 1886 and became the pastor of Seventh United Presbyterian Church in Philadelphia. The 1890s were traumatic and extremely troubling years for the young pastor. In 1891 tragedy struck when Kyle's wife died in pregnancy with twin daughters (Kyle 1907, p. 130). He married again in 1895, but a few years later his second wife died, leaving Kyle with a little daughter to raise. During these difficult years, Kyle was becoming better known in the UPCNA for his mission's leadership, and in 1894 Kyle 
received an honorary D.D. from the UP's Cooper College in Sterling, Kansas. Earlier in 1889 Kyle had become a member of the UPCNA's board of foreign missions and would serve in this capacity for thirty-three years. In the late 19th and early 20th centuries the UPCNA had a strong missionary presence in Egypt and this proved to be crucial in Kyle's scholarly development and his interest in Egyptology. While serving as pastor at Seventh United Presbyterian Church in Philadelphia, Kyle had parishioners who did missionary work in Egypt, and Kyle also did short term missions work there, but he was doing more. As a pastor, Kyle had developed a relationship with the famed scholar, Max Müller, professor of Egyptology at the University of Pennsylvania. Müller was aware of Kyle's missionary activity in Egypt and asked him to research archaeological data for him (Lapp 1994, p. 238). Kyle did this work for Müller, the two became friends, and Kyle became a member of the University of Pennsylvania's archaeology club, or as one profile from 1907 listed it "department."

\section{The Emergence of an Evangelical Biblical Archaeologist}

Kyle the aspiring archaeologist sought to connect himself to leading archaeologists. He became a friend of Sir Flinders Petrie, the famed British Egyptologist, and worked on excavations and explorations with him. In 1905 the veteran UP minister and author, James Price, wrote that the forty-seven-year-old Kyle was a "scholarly man and a close student" who "has for years been devoting attention to archaeological studies with the laudable aim of illustrating and defending the Holy Scriptures" (Price 1905, pp. 137-38). Kyle's studies led him to publish a 1905 pamphlet, Egyptian Sacrifices: A Study of Scenes in Painting and In Sculpture (Kyle 1905). In 1906 William McEwan, pastor of Pittsburgh's Third United Presbyterian Church, labeled Kyle one of the "first archaeologists" (McEwan 1906, p. 439). Kyle appears to have been developing a reputation as a pioneering Christian archaeologist because of his writing and field work. In the winter of 1908, it was reported that Kyle was on an archaeological dig with Edouard Naville-a professor from the University of Geneva and a specialist in large monuments and temples (Kyle 1908, p. 197). Naville was Swiss but had connections to British evangelicalism and once served as president of the Evangelical Alliance (Hall 1927). Kyle became close to Naville and later he dedicated his 1920 book, Moses and the Monuments, to his Swiss friend. In 1908, at the age of 50, Kyle's growing reputation as a scholar led to his appointment as permanent lecturer of biblical archaeology at Xenia. Kyle would serve Xenia one semester per year in this role until 1915 when he became a full professor. Significantly, Kyle noted that Xenia "was the first Theological Seminary in America to give distinct recognition of the new science of biblical archaeology as a separate Department of Seminary work" (Kyle 1917, p. 2). Up until 1916 most Xenia Seminary graduates were from UP colleges, but by 1916 half of the graduating class was from Moody Bible Institute where Kyle sometimes taught summer school (A Special Summer Course, Moody Monthly, 1922, vol. XXII, p. 1065). During this time Xenia also educated several African American students from nearby Wilberforce College, an A.M.E. institution. These two associations reveal, to some degree, the populist orientation of the United Presbyterians in the early part of the 20th century. While Egyptology and archaeology were mostly associated with the more elite American universities, Harvard and Penn, Kyle sought to make the impoverished and humble Xenia a center of archaeological scholarship, but could it be done?

Kyle taught seminarians and participated in excavations, but also in scholarly organizations that were committed to the Bible's trustworthiness. He was active in the Bible League of North America and in this organization's publications. He served as an associate editor of The Bible Teacher which later changed its name to The Bible Champion. He served in this role with his southern Presbyterian colleague William McPheeters, an Old Testament professor at Columbia Seminary and an ardent critic of liberal trends in the PCUS (the southern Presbyterian denomination). ${ }^{1}$ Kyle also served as the archaeology editor of the Sunday School Times and developed a higher academic profile as editor of Bibliotheca Sacra, a long-standing academic journal founded in 1844 and previously published by 
Oberlin College, but by 1922 under the auspices of Xenia Seminary. Kyle worked with evangelical groups and publications, but in 1911 he became a member of the Society of Biblical Literature and wrote for the Journal of Biblical Literature. Kyle worked hard to operate in both evangelical and in more mainstream academic forums. By 1916 G. Fredrick Wright of Oberlin College noted in his autobiography that "Professor M. G. Kyle" has been "recognized as an authority on the archaeology of Egypt the world over" (Wright 1916, p. 397). Kyle's reputation was growing through his pen and his spade.

\section{Evangelical United Presbyterian Scholarship and Its Influence}

The UP's populist orientation led its scholars to engage, learn from, but also turn away from radical liberal scholarship. Five of the six UPCNA colleges were in rural areas, many UP General Assemblies were held in small towns, and in many ways the UPs were contributing and aligning themselves with the wider evangelical movement. In the 1926 commencement address at the UP's seminary in Pittsburgh, the institution's president, the venerable John McNaugher, told students "The immediate risk to which you are exposed is the popularized evolutionary view of religion." He added, "Between its bloodless categories and the orthodoxy in which you have been reared there is an unbridgeable gulf" and he noted that "Modernism, it is but a thinly veiled form of Unitarianism, that is rotten from the floor to the roof" (Mueller 1926). However, where did this UP antimodernism come from? The UP's biblical convictions and populist orientation had led them to promote what they regarded as the fundamentals of the Christian faith against their critics. To be sure, four writers of The Fundamentals (1910-1915) who have often been identified as "Presbyterians" were in fact individuals from the United Presbyterian tradition. The four writers include Kyle and William G. Moorehead of Xenia Seminary and the Scottish UP theologian James Orr and the Scottish UP pastor/scholar Thomas Whitelaw. Despite being numerically smaller, the United Presbyterians were as well represented in The Fundamentals as their mainline Presbyterian brethren. Perhaps the amplification of evangelical United Presbyterian scholarship was the result of the fact that one of the editors for the project was Louis Meyer, a former Jew who had become a Reformed Presbyterian (RP). The Presbyterian Seceder and Covenanter traditions were playing a role in public theological and intellectual debate and their populist sympathies were intentionally and strategically quite noticeable.

In his book Old Testament Critics Whitelaw argued that "The every-day religious man who has studied the Word of God under the teaching of the Spirit of Christ is an expert of another and, some hold, of a higher order than merely language and literature" (Whitelaw 1903). The greatest UP scholar of the period was James Orr and his specialty, which he had developed over seventeen years as a parish pastor, was mastering the arguments of German scholars in an effort to defend classical Christian truth. Orr's mature scholarship combined with an overt populism led him to conclude that "simple minded" people actually had a superior ability to grasp religious truth (Scorgie 1988, p. 144). Orr noted that "When Jesus introduced His religion into the world He did not choose "scholars."" Extreme radical critics according to Orr were "closet recluses" and not connected to "experimental religion." The populist instincts and scholarship of UP scholars led them to spurn radical higher criticism of the Bible. To be sure, Kyle, Orr, Whitelaw, and other UP scholars all wrote weighty books analyzing liberal Old Testament criticism. In 1920 George L. Robinson, a professor at McCormick Seminary, argued that "All fair minded readers ... will, because of its thoroughness rank Kyle's volume [Moses and the Monuments] alongside that of James Orr's "The Problem of the Old Testament" (1906), as another formidable stroke against the Oxford School of Modern Criticism" (Robinson 1920, p. 345). In his first book Kyle wrote that he would "neither take the toplofty way of those who assume the higher criticism to be the sum of all wisdom, nor the imprecatory way of those who proclaim it [higher criticism] as a "doctrine of devils'" (Kyle 1912, p. 6). For the UPs, destructive higher criticism could be rebutted by Christian scholarship of the Bible, but also by biblical archaeology. In 1906 James Orr had even argued that "Nothing in the 
whole course of the last century is more remarkable than the recovery of the knowledge of ancient civilizations through the labors of explorers and the successful decipherment of old inscriptions" (Orr 1914, p. 395).

Despite the rapid growth of biblical archaeology in the late 19th and early 20th centuries, Kyle demonstrated in 1912 how archaeology had been omitted from almost all the great Bible encyclopedias and dictionaries. Kyle noted, "Since encyclopedias have little or nothing to say on the subject of archaeology and criticism, it is to be expected that critics, who are contributors to all the encyclopedias, will have as little to say in their own individual writings. The expectation is not disappointed" (Kyle 1912, p. 13). Kyle considered this a major blunder by liberals and in his mind liberal "Higher criticism" of the Bible was guilty of "circling round and round in its enclosed basin" of the biblical text. Literary criticism of the Bible was not enough, and archaeology provided a new way to deal with critical issues and James Orr even predicted that archaeology would "before long, [come] to control both criticism and history." Orr's agreement with Kyle's scholarly agenda is detected in the fact that Orr, his Scottish UP brother, wrote the "Introduction" to Kyle's 1912 book The Deciding Voice of the Monuments in Biblical Criticism noting that Kyle's historical arguments for the trustworthiness of scripture have been made "with much clearness and success." Indeed, Kyle wrote that his greatest debt was "certainly to none more than to Professor James Orr" (Kyle 1912, p. xii). In 1913 Luther Townsend, professor emeritus of Boston University, argued that Kyle was a "Egyptologist with perhaps no equal in this country." Writing in The Bible Champion Townsend held that Kyle had "buttressed the old theology at points where the new theology men had thought everything had been demolished" (Townsend 1913, p. 93). In an era of heated debate about the historical trustworthiness of the Bible, Kyle's goal was to use archaeology as a new tool to carefully, as he said, "answer the questions of the critics."

Yet, not all was well in Kyle's scholarly efforts. George Barton of Bryn Mawr College was not impressed with Kyle's scholarship and in 1913 criticized Kyle's book The Deciding Voice in Biblical Criticism in the Journal of Biblical Literature. Barton claimed that "those who seek by means of archaeology to overthrow criticism are following an ignis fatuus [a deceptive hope]" (Barton 1913, p. 252). He alleged various places where Kyle had made archaeological mistakes and argued that "archaeological evidence in favor of critical views exists." In order to turn the tide against skeptical and liberal scholars-like Barton-the UPs promoted archaeology, but they also sought to provide a feast of scholarship that could counter the critics. Despite having help from Kyle, Orr worked himself literally to death on his last project, the massive International Standard Bible Encyclopedia (ISBE) (released in 1915). The goal of this work was to help pastors, laypeople, and scholars deal with attacks on the trustworthiness of scripture. In this enduring encyclopedia, dedicated to what Orr termed "reasonable conservatism," the goal was to provide "fairness of statement on all subjects" and counter anti-supernatural scholarship which "eviscerates Christianity of most of the vital truths which the Church, resting on Scripture, has always regarded as its essence" (Orr 1930, p. viii). Kyle wrote numerous articles in the ISBE and Orr thanked him and noted that Kyle "unselfishly aided in the production of this work" (Orr 1930, p. xi). Ultimately, Kyle became the revising editor of ISBE, seeking to make the work even more conservative.

\section{Kyle's Influence and Legacy}

In 1919 Kyle gave the Stone Lectures at Princeton Seminary on archaeology and the Pentateuch. On several occasions in the 1920s Princeton Seminary professors J. Gresham Machen and Robert Dick Wilson lectured at Xenia and in 1927 and 1928 Kyle lectured at Princeton. On 24th May 1929, The Cedarville Herald reported that Kyle and Machen, who was just days away from leaving Princeton, were lecturing together at the Cedarville Bible Conference in Ohio (College Conference Attracting Ministers, The Cedarville Herald, 24 May 1929, p. 1). Just a few years earlier, in 1925 when Machen and Princeton Seminary students founded the League of Evangelical Students, Kyle immediately joined the LES 
board and spoke, along with Machen, at the first LES national convention held at Calvin College. In 1926 the first edition of the LES publication The Evangelical Student featured an abbreviated version of Kyle's address at Calvin (Kyle 1926). Despite the prominence of other speakers, such as Machen, the only professor to have his work profiled was Kyles's paper on biblical archaeology. In 1926 Kyle made an invitation and was successful in bringing the LES national convention to Xenia. While Machen was being marginalized for his LES work Kyle was made Moderator of the UPCNA in 1927. In April of 1932 The Evangelical Student offered a brief biographical statement on Kyle noting:

MELVIN GROVE KYLE, D. D., LL. D., is known for his excellent archaeological contributions. The League has been fortunate in the presence of such a defender of the Word on its Advisory Board. His works are known to those who have followed the work of the League (The Evangelical Student, April 1932, p. 41).

Significantly, Machen and Kyle were the only Presbyterians to serve on the LES board in its early years. Kyle spoke at various LES national conventions and his books were promoted in The Evangelical Student and shortly before his death in 1933 Kyle contributed his views on how evangelical students should deal with the skepticism of other students and the various ways in which biblical Christianity was being attacked. Kyle's commitment to the UPCNA and the LES were undeniable, but he was also trying to influence mainstream scholarship.

In 1921 Kyle served as a lecturer at the American Schools of Oriental Research in Jerusalem and taught there again in 1926, 1928, 1930, and 1932 (Davis 1995, p. 171). On Kyle's first visit ASOR's director, the famed William Foxwell Albright, found Kyle to be a charming and tolerant biblical scholar who never argued (Running and Freedman 1975, p. 90). Perhaps this is why he was invited back, and a good friendship formed between Albright and Kyle. While at ASOR Kyle and Albright pursued exploration and excavation and together did work in 1924 in the southern coastal part of the Dead Sea and in 1926, 1928, 1930, and 1932 at Tell Beit Mirsim. Later, Albright wrote,

The writer used to meet Dr. Kyle occasionally, before coming to Palestine in 1919, at learned society meetings. In those days, the fact that we were apparently at antipodes with regard to most crucial biblical and oriental problems seemed to preclude all real friendship. In the spring of 1921 Dr. Kyle came to Jerusalem ... for a stay of several weeks as lecturer in the School, during the writer's year as acting director. The acquaintance then developed soon ripened into friendship ... We seldom or never debated biblical questions, but there can be no doubt that our constant association with the ever-recurring opportunity for comparing biblical and archaeological data has led to increasing convergence between our views, once so far apart. To the last, however, Dr. Kyle remained staunchly conservative on most of his basic positions, while the writer has gradually changed from the extreme radicalism of 1919 to a standpoint which can neither be called conservative nor radical, in the usual sense of the terms (Albright 1933, pp. 5-6).

Kyle and Xenia with the help of Albright successfully put themselves on the scholarly map of archaeological research. Their work in pottery chronology became well known in the discipline and artifacts from these excavations were displayed prominently at Xenia-and laterally at Pitt-Xenia and now housed as the Kelso Museum of Near Eastern Archaeology at Pittsburgh Theological Seminary. The origins of this museum are clearly attributable to Kyle's "evangelical UP scholarship" and to his devoted protégé James Leon Kelso, also an evangelical UP archeologist, who taught at Xenia, Pitt-Xenia, and Pittsburgh Seminaries from 1923 to 1963, the only person to teach at all three distinctively different institutions. More importantly for the history of archaeology, it appears that Kyle is to some degree responsible for moving Albright down a less radical scholarly path that held to the Bible's historical trustworthiness. 
In 1924 Kyle gave a lecture on archaeology and the Pentateuch in London at the Victoria Institute. After Kyle presented his paper various people responded. Dr. Alfred Schofield, a London Harley Street medical physician, noted

For many years the clearness of the Americans has much impressed me. At Harley Street, if I had an American patient I got an intelligible and orderly statement of symptoms, quite different from any English sufferer. To what to attribute this valuable characteristic, so marked in the able paper to-day, I know not. Whether it is due to the clarity of the atmosphere, producing a corresponding clearness of mental vision, or whether it springs from some more recondite source, I know not. Of its charm and value there is happily no doubt ... It is delightful to find as I do week by week the most valuable and quite new testimony coming from America on Bible subjects of the first importance, and proving by quiet argument the authenticity and accuracy of Holy Writ, in refreshing contrast to the ex parte and unbalanced statements subversive of Scripture, heard here in much unwearied repetition" (Journal of the Transactions of the Victoria Institute, 1924, Vol. LVI, p. 37)

It is interesting to note that Schofield like Albright found Kyle to be charming. A.H. Finn, a British Old Testament Scholar, seemed to agree with Kyle and said that "the general trend of the argument is forcible" (Journal of the Transactions of the Victoria Institute, 1924, Vol. LVI, p. 39). In 1952, Donald Wiseman, a leading British evangelical archaeologist, reminded members of the Victoria Institute of Kyle's memorable lecture.

One admirer of both Machen and Kyle was Joseph P. Free. In the 1930s Free was troubled by Presbyterian liberalism and sided with Machen. Free became a committed evangelical Presbyterian and developed a great enthusiasm for biblical archaeology. Free began teaching biblical archaeology at Wheaton College in 1936 and continued for several decades. In a 1956 a Wheaton College biblical archaeology brochure, Free featured Kyle's name and Kyle's view that the evangelical approach to the discipline "seeks not merely to discuss problems, but to solve them" (Larsen 2005, p. 5). ${ }^{2}$ Indeed, in an April 1932 edition of The Evangelical Student Kyle argued that his archaeological goal was "to answer those questions" he had many years ago at Muskingum (Kyle 1932, p. 26). It appears that Free's approach to archaeology was influenced by Kyle and Free cited Kyle's work and Albright's commendation of Kyle in Free's 1950 work Archaeology and Bible History. In addition, Kyle's influence extended to Robert McQuilkin who had studied privately under Kyle for his UPCNA ordination and in 1923 founded Columbia Bible College and helped develop evangelical and fundamentalist movements in the American South. At Westmont College in Santa Barbara, Kenneth Munroe, who had earned a Xenia Th.D. under Kyle in 1929 taught at the school for several decades, a school that was partially founded by evangelical UP clergyman and linguist, Elbert McCreery. The famed Baptist fundamentalist A.C. Dixon recognized Kyle's scholarship and took him to China on a tour defending historic Christianity (Larsen 1998, p. 737). J. Oliver Buswell noted that he once heard Kyle give his personal testimony. Buswell, a Wheaton College president, noted that Kyle "took his Bible between his hands and said, 'Ladies and gentlemen, this book is true. I have taken it and lived with it in the very cities of ancient Canaan, and it has proved to be true at every point of testing'"' (Buswell 1962, p. 213). For Kyle archaeology was no enemy of faith. At his death in 1933, Kyle was simultaneously lecturer in biblical archaeology at Pitt-Xenia, Louisville, and Dallas seminaries.

Melvin Grove Kyle was a humble evangelical United Presbyterian scholar and biblical archaeology was his passion along with his personal faith in Christ and his word. For those who Kyle felt were in error on biblical, archaeological, and theological issues, Kyle sought to, as he said, "answer their questions." Many of their questions had been his questions. Kyle was able to establish Xenia as a center for archaeological research and scholarship and this continued in both Pitt-Xenia and at the current Pittsburgh Seminary. ${ }^{3}$ As we think of Old Princeton, we need to remember the Princeton-Xenia alliance and the friends that conservatives in the PCUSA found in the UPCNA. Kyle appears to have been winsome and Albright noted that Kyle was excellent at making "ill wishers into friends." 
Kyle was an evangelical United Presbyterian who lived out the UP motto "The Truth of God-Forbearance in Love." Kyle was an influential evangelical archaeologist in the world of scholarship and the church. In fact, the evidence shows that Kyle and the UPs exerted an important influence on evangelicalism well beyond their own denomination. One way this can be seen is by analyzing the various connections the UPs had to the League of Evangelical Students. To grasp the advancement of evangelical scholarship it is to this organization that we now turn.

\section{The Rise of the League of Evangelical Students}

On 21 October 1924, a meeting was held in Miller Chapel at Princeton Seminary to debate the founding of a new organization known as the League of Evangelical Students. Prior to this event the seminary had been a part of an inter-seminary group, but its members had recently become troubled when the organization allowed a Unitarian school to join. To a packed audience, students spoke for and against leaving the inter-seminary organization. Sitting in the back pew of the chapel that day was a new seminarian, Charles Woodbridge, and he did not like what he was hearing. During a pause in the discussion Woodbridge rose to his feet and spoke against leaving the established organization. To his mind, the controversy involved personalities and not theology, but his arguments were rejected, and the students voted to leave the inter-seminary group. As Woodbridge was leaving the chapel, he ran into J. Gresham Machen, assistant professor of New Testament, who bluntly told him, "In your speech tonight you were exactly 100\% wrong!" (Woodbridge 2017, p. 75). ${ }^{4}$ Machen's institutional legacy includes Westminster Seminary, the Independent Board of Presbyterian Foreign Missions, the Orthodox Presbyterian Church, and Presbyterian and Reformed Publishing but he also created another key organization, the League of Evangelical Students (hereafter LES). Machen had a deep commitment to this student group and worked to expand its reach. His involvement in the LES reveals his ecumenical commitments and the support he received from other key scholars, administrators, and church leaders. The LES was launched by Machen and Princeton Seminary students. Many Presbyterians were involved in the organization and Presbyterian opposition to theological liberalism was perhaps slightly more unified than previously realized. The LES was a key organization in transmitting evangelical theology and Machen's well-known critique of theological liberalism.

The LES inspired students and helped them form "evangelical" minds for ministry and scholarship. Some of the most famous scholars in evangelicalism at the time were active in the LES, and some students who participated became well known evangelical scholars themselves. For instance, George Eldon Ladd, who later served as a noted Fuller Seminary New Testament scholar, served as a Gordon College student on the executive committee of the LES in 1932-1933, and Vernon Grounds, future ethicist and longtime president of Denver Seminary, served as vice president of the LES in 19391940. ${ }^{5}$ In order to promote evangelical thinking the LES launched The Evangelical Student, published three times a year, and claimed that it was "The only American magazine exclusively devoted to the propagation and defense of historic, evangelical truths among students" (The Evangelical Student, January 1931, back cover). In 1928 the LES stated in its publication that it was committed to "promoting the intellectual defense of the faith" and to "exalt[ing] our Lord Jesus Christ ... as presented in the inerrant Word of God" (The Evangelical Student, October 1928, inside cover). The LES promoted learning, scholarship, Bible study, spiritual life, and evangelism all in the hopes of expanding an evangelical witness in America's institutions of higher learning. Moreover, the LES developed a Bible study curriculum titled Christian Truth Today: A Presentation and Defense of Historical Supernatural Christianity for College Students. The LES chapter at the PCUSA's Albany College in Oregon (now Lewis and Clark College) was creative and started its own publication known as The Campus Witness which "gives evangelical messages and announces the League's activities" (The Evangelical Student, January 1937, p. 32). The LES chapter at Eastern Nazarene College near Boston did the same with their publication 
Crusader. In addition, the LES sponsored regional conferences and a yearly national convention where established evangelical scholars and missionaries lectured and preached. The LES also developed week-long summer conferences for Christian and non-Christian students that combined teaching and worship with swimming and canoeing. The stated purpose of the summer conferences was to "draw students away from the numerous liberal student conferences held at this time of the year" (The Evangelical Student, April 1936, p. 33). The LES presented itself as an orthodox alternative and dissented from the more liberal approach of the Student Christian Movement, which the LES accused of theological modernism and communism.

\section{The Growth and Message of the LES}

Professors associated with the LES also went out to speak at chapter meetings at other institutions, providing these scholars an important avenue to reach a broader audience and grow the organization. In 1926 the LES had fifteen chapters, in 1930 thirty chapters, and by 1935 fifty-one chapters. The LES continued to grow and by 1939 had sixty chapters. There were chapters at Christian colleges, state colleges and universities, and at some private intuitions and even at Ivy League schools such as Cornell, Columbia, Penn, Princeton University, Harvard, and the Harvard Business School. The LES student hymn "Leaguers for Christ" was written by a Columbia University student William Young. The first stanza in the song's six verses reads, "Leaguers for Christ, by His Grace called to conflict" (The Evangelical Student, October 1937, p. 21). While this song might seem defensive LES leaders did face their share of problems. In January 1937, LES officials reported that the Presbyterian Student Pastor at the University of Pennsylvania "maneuvered to prevent the Eastern Regional Conference of the League from being held at the "Penn C. A." building" (The Evangelical Student, January 1937, p. 32). After the LES was denied its meeting space the conference was held at the Reformed Presbyterian's Second Church of the Covenanters. Reformed Presbyterians embraced the LES, and an LES chapter was maintained at the RP seminary in Pittsburgh. Despite opposition the LES held firm to its evangelical convictions. In 1926 LES leaders objected to "widespread assertions that modem scholarship has rendered conservative Christianity untenable" (The Evangelical Student, April 1926, p. 4. They )organized to "record their opposition to the stealthy progress of religious unbelief."

In 1930 the University of Pennsylvania LES chapter reported in The Evangelical Student that "One of our members is editor-in-chief of one of our student magazines and is introducing Machen to some thousands of students thereby" (News and Notes, The Evangelical Student, January 1930, p. 48). One of the aims of the LES was to promote evangelical thought through literature. In April 1931, the Lafayette College LES chapter reported that "Since the Bible Department is so filled with destructive Higher Criticism, books with the evangelical viewpoint have not only been enlightening but entirely a revelation to some men. Our supply of tracts has run short more than once" (The Evangelical Student, April 1931, pp. 43-44). The LES was interested in opposing liberal methods of biblical scholarship, and numerous articles in The Evangelical Student were written to counteract perceived infidelities. In 1932, Calvin Knox Cummings, a Presbyterian, and a graduate of Lafayette College, wrote that "Reading-matter which the League has been instrumental in supplying such as Dr. Machen's book "What Is Faith?" has aided me greatly in answering the doubts and questionings of the mind." Cummings added,

THE average evangelical Christian student as he stands in the midst of a hostile campus feels paralyzed though he ardently wishes he could "do something". I was not above the average. Lonely of heart, the mind clouded by honest doubts, and the soul highlighted by being exposed to an anti-Biblical, anti-theistic, antiChristian "Christianity" I found myself powerless: ... "The League" by God's grace was the great power-house which supplied the strength, the vision, the opportunities so sorely needed." (Cummings 1932, p. 17) 
Apparently, some students were transformed by their experiences with the LES. Kenneth Kantzer, later dean of Trinity Evangelical Divinity School, remembered how he moved from atheism to faith in Christ after meeting members of the LES at Ashland College in Ohio. He noted, "I would go to them with the question: How in the world do you believe all of this?" Kantzer added, "They would recommend books for me to read, and over the course of a year I came to a firm faith in Christ" (Hertz 2002" Mary Hunt established the first chapter at an all-female institution-Wilson College in Pennsylvania-and told her fellow Leaguers that ")It is in connection with my League work that I have learned that adversities lead to blessing, that "prayer changes things", and that what is impossible with man is possible with God" (Hunt 1932, p. 18). She added that the LES "caused my faith to grow." The LES chapter at the University of Minnesota was led by women students and a woman math professor. A small Presbyterian church near the campus supported the LES chapter and in 1931 Machen spoke at a U of M LES event to an estimated one hundred people and a few $\mathrm{U}$ of $\mathrm{M}$ professors (Keillor 2008, p. 183). It appears that in some cases the LES made a strong impact on both male and female students' lives.

From 1925 to 1929 the LES headquarters was at 25 Edwards Place in Princeton. In 1929 the LES headquarters was moved to Wheaton and in 1934 transitioned to Philadelphia. The LES also had an affiliated group known as the League of Evangelical Students of China, with twenty chapters. Moreover, the LES participated in the International Conference of Evangelical Students and developed relationships with leaders of the expanding British Inter-Varsity Christian Fellowship. Dr. Howard Guinness, a medical school graduate and Inter-Varsity official, spoke at the 1928 LES national convention, but wrote in his diary that the LES is "appealing to the mind alone and dealing with subjects as Christ's Deity, Theism, etc ... . Dead theology is stifling the league" (Hunt 1991, pp. 64-65). Nonetheless, the Englishman was impressed with the LES chapters he visited at the University of Washington and at the University of British Columbia. In 1932 the University of Washington LES chapter reported that they had been meeting weekly and that Roy Brumbaugh, the energetic conservative pastor of First Presbyterian Church in Tacoma was "giving us a series of talks every other week" (The Evangelical Student, April 1932, p. 42). LES national conventions were held at various Presbyterian institutions including Xenia Seminary (St. Louis) in 1927, Point Breeze Presbyterian Church (Pittsburgh) in 1932, Tenth Presbyterian Church (Philadelphia) in 1935, and Queen's College in Charlotte in 1937. The February 1936 national convention attracted fifteen hundred students; various sessions at that meeting attracted between two hundred and three hundred students (Attendances at the Convention, The Evangelical Student, April 1936, p. 34). Remarkably, Presbyterians of various stripes worked together and participated in the League's efforts.

\section{The LES, Presbyterians, and the Battle with Theological Liberalism}

Machen himself was the driving force behind the LES. He appears to have spoken at almost all the national conventions until his death in January of 1937. He also spoke at numerous regional conferences and visited various LES chapters. In October of 1935 it was reported that Machen would send free copies of two of his books Christianity and Liberalism and What is Faith? to any student who requested one. His presence and scholarly stature were revered by LES members. In the April 1937 edition of The Evangelical StudentMachen's death was described as a "irreparable loss." The editor wrote that Machen "loved students" and that the LES was "close to his heart." At LES conventions it was noted that he would "give liberally of his time" and that the scholar "would travel hundreds of miles to speak to a humble group of students" (Cummings 1937, The Evangelical Student, April, pp. 1-2). Evangelical scholarship seems to have been revitalized through the strange twists of the 1920s and 1930s largely because of Machen's vision and commitment to the LES.

Although Machen was the preeminent name associated with the League, it included many other leading scholars as well, many of whom were Presbyterians. Two PCUSA scholars who were omnipresent in LES events and publications were philosophy instructor Gordon Clark of the University of Pennsylvania and J. Oliver Buswell, president of Wheaton 
College. Early on, the majority of Princeton Seminary and the United Presbyterian's Xenia Seminary professors were leaders in the LES, and the president of Xenia, Melvin Grove Kyle, served on the advisory committee with Machen and three other professors. Kyle was a writer of The Fundamentals, served as moderator of the UPCNA in 1927, was an accomplished biblical archaeologist, and made all Xenia students members of the LES. He spoke at several LES conventions and wrote for the LES publication. Kyle also promoted the LES by hosting the LES national convention at Xenia. Clearly, there was a strong connection between the LES and the UPs. To be sure, John Orr, longtime professor of Bible at the UP's Westminster College in Pennsylvania, spoke at the 1935 national convention (The Evangelical Student, January 1935, inside cover). Perhaps he attended the convention with his close protégé John Gerstner, who later served as longtime professor of church history at Pittsburgh-Xenia and Pittsburgh seminaries.

Hugh Kelsey had graduated from Xenia Seminary in 1903, and throughout his career he took a hardline stance against alcohol. He served as a UP pastor before becoming a professor of Bible in 1919 at the UP's Muskingum College in New Concord, Ohio. Kelsey also served as a vice president of the college and was the faculty leader for the school's LES chapter. He described his leadership in the league as "a very happy experience" (Kelsey 2007, p. 50). In retrospect he noted that "Often times we had as many as 100 students ... [and the League] never seemed to lose its appeal" (Kelsey 2007, p. 50). Two Muskingum evangelical students who emerged out of this LES chapter were Addison Leitch, future president of Pittsburgh-Xenia Seminary, and John Galbraith, who later served as the longtime general secretary of the OPC's foreign missions committee. Kelsey sided with Machen and other conservative scholars against the inroads of liberal theology and biblical scholarship, declaring in the pages of The Evangelical Student that liberalism was leading to "spiritual starvation and suicide" (Kelsey 1931, pp. 7-8). During the late 1920s Kelsey also objected to a moderately liberal Muskingum Bible professor, G. Reid Johnson, who was ultimately dismissed from the college. In the 1920s and 1930s Kelsey spearheaded a robust evangelical witness at Muskingum.

In 1933-at sixty years old-Kelsey was chosen to be the new president of the UP's Sterling College in Kansas. However, why was Kelsey selected? The conservative UP Synod of Kansas was upset with Kansas and Oklahoma public colleges and universities and stated that they were guilty of a "systematic and concerted effort on the part of man to destroy our young people's faith in God" (Julich 2018, p. 2). ${ }^{6}$ Apparently, Kelsey, known for his conservatism through the LES, was brought into the rural college to provide robust Christian leadership in the face of growing secularism. Yet, shortly after Kelsey arrived, the college lost its accreditation. According to Kelsey, accreditors, whom he referred to as "university men," arrived on the campus with the "odor of alcohol" on their breath. Kelsey believed that the North Central Association's report was "savagely adverse and in part untrue" (Kelsey 2007, p. 65). Kelsey kept Sterling evangelical, and retired all school debts in 1946, but it was not until 1957 that Sterling regained its accreditation under the administration of William McCreery, a former Wyoming UP clergyman and son of Westmont College (California) founder Elbert L. McCreery. In an essay titled "The Christian College as a Spiritual Force" Kelsey blasted secular scholars, noting that "learned men allow themselves to entertain grotesque conceptions of a great and holy God." He added, "they rather resent the idea that they need to personally and consciously deal with God." The Sterling president noted that "in its boastful pride, modern scholarship has ... pushed God and His fatherly love farther and farther away" (Kelsey 1937, p. 338). According to Kelsey, Christian institutions in the face of such secularism "should at once become Christ centered." For Kelsey "the college president must be firm in his purpose and sufficiently courageous to pay the price that is exacted by such a course." Kelsey, who was also a vice-moderator of the UPCNA, cemented Sterling's evangelical approach and strongly opposed secular approaches to education. Like many other Xenia graduates Kelsey would not yield to secular pressure or liberal theology. Among Presbyterian colleges Sterling was different and became known for its strong Christian emphasis. 
At the PCUSA's Hastings College in Nebraska, seventy-year-old John J. Boggs, a former missionary to China and now professor of Greek and Latin, launched an LES chapter, hoping to shore up his school's evangelical witness on the central Nebraska plains. In a 1935 article in The Evangelical Student Boggs, a McCormick Seminary graduate, unleashed a torrent of criticism on theological liberals,

when we abandon God's revealed truth, throwing away one after another of the great saving facts of Christianity: "liberalism," rationalism, agnosticism, atheism,-these are the regular steps, and with the descent there is very often an accompanying abandonment of moral principles (Boggs 1935, p. 23).

Boggs held that Christianity had become infiltrated by a movement that was not Christian. It appears that Boggs was rehashing Machen's argument in his classic book Christianity and Liberalism (Machen 1923). He argued that the "most fatal and seductive of all errors in the history of human thought arose when two different systems of religion came to be called by the same name, Christianity." Boggs passionately wrote, "We must make a clear distinction between true Christianity and anything with that name that is false or incomplete, lacking its vital elements." The Hastings classicist held that there was a "true, authentic Christianity that has come down from the founding of the church, reaffirmed at the Reformation, and is actively working today." However, he added, "there is opposed to this, disguised under the same name, a system or group of systems, non-Biblical." Boggs believed that the opponents of historical Christianity should not get upset when he called them non-biblical. He noted, "They do not derive their system from the Bible, so of course they should not object when it is called non-Biblical." In the midst of Machen's own church court case, Boggs concluded that "The false religion that calls itself Christian may largely prevail for a time, and it may use organized power to persecute true believers. But we know from the word of God that a remnant shall remain" (Boggs 1935, p. 25). There was little Boggs could do, however, to counter the prevailing forces at Hastings, which pursued a largely liberal Presbyterian path during the twentieth century.

While the LES was mainly a Northern operation some southern Presbyterians were made honorary members. Two prominent ones were W.W. Moore, president of Union Seminary in Richmond, and William Childs Robinson, professor of church history at Columbia Seminary in Georgia. Robinson took an active role in the LES and wrote for its magazine, spoke at its events, and served as a trustee from 1932 to 1939. In October of 1935 it was reported that a majority of the Columbia Seminary students wanted to form an LES chapter, but that their petition was denied by their faculty-except for Robinson (Students Favor League at Columbia Seminary-Faculty Opposes, The Evangelical Student, 1935, p. 3233). The only southern Presbyterian seminary to allow an LES chapter was Austin Seminary, but this group existed only from 1929 to 1934. Andrew K. Rule, professor of apologetics and church history at Louisville Seminary, spoke at the 1935 LES national convention and published in The Evangelical Student. He robustly defended Christian supernaturalism. One honorary member of the LES, Fred Z. Brown, was pastor of First Presbyterian Church, Texarkana, Texas, while also serving as an adjunct professor of church history at the Evangelical Theological College (Dallas). Robert McQuilkin, president of Columbia Bible College in South Carolina, was also active in the LES. McQuilkin was a private student of Kyle and was ordained in Philadelphia by the UPCNA in 1917. Interestingly, McQuilkin believed that liberal southern Presbyterian leaders were using the dispensational issue as a way of discrediting all southern conservative Presbyterians as part of efforts to achieve liberal dominance in the PCUS. The UP pastor working in the south noted, "The interest of some of the strongest enemies of premillennialism is to bring the Southern Presbyterian Church that new religion called 'modernism.'" (Glass 2001, p. 147). Southern Presbyterian support for the LES appears to have been limited because dispensationalists were involved in the organization and perhaps because of Machen's own ecclesiastical trial and appeals in 1935 and 1936.

At Hampden-Sydney College in Virginia the school's president, Joseph D. Eggleston, was an advocate of the LES and wrote for the organization's periodical. In the early 
1920s Eggleston had awarded Machen an honorary D.D., and in 1929 Machen gave the baccalaureate address at the college. Eggleston apparently agreed with Machen's analysis of the perils of liberal theology and associated himself with the LES. In 1937 Eggleston, a former Virginia Tech president, wrote in The Evangelical Student that he once uncritically accepted Darwin, Huxley, and Spencer, but that he had abandoned his earlier views and embraced orthodox Christianity. Eggleston argued:

I am in entire accord with the demand that research should be unhindered; but I am convinced that those engaged in teaching our youth should resist the temptation to teach, in the names of Scholarship and Science-that is, in the name of Truth-conclusions which are neither scholarly nor scientific (Eggleston 1937, p. 4).

Eggleston wrote, "The idea that to disbelieve is scientific, and to believe is unscientific, is very prevalent, but none the less a false assumption." He wrote that the "sanest ... people in the world are Christians, in the orthodox, fundamental sense of that word." He argued, "We should make up our minds that we are facing the most serious situation that has ever confronted Christian people in this country." The learned president went on, noting that

many of our universities and colleges are sending out from their halls young men and young women who have been taught that spiritual truth can be discovered by brain toil; by long searching among various religions; painstaking research in the realms of science, and in the fields of psychology and philosophy. They are taught that a belief in revelation is unscientific and cannot be accepted by anyone who has a respect for his intellect (Eggleston 1937, pp. 8-9).

Eggleston was alarmed by what he considered the many false philosophies in American universities, but he also noted that "At the rate the Church is progressing to the left, the situation takes on an outlook menacing to those Christians who are loyal to Jesus Christ" (Eggleston 1937, p. 21). He reminded his readers "I have been in intimate touch with educators and their teachings for nearly fifty years, I hope that you will not regard my observations and conclusions as presumptuous." Eggleston was not afraid of challenging the educational establishment and its secularism. To be sure, one biographer wrote in 1943 that Eggleston "apparently did not fear any consequences or political opposition whatever."7 Arising out of Eggleston's Hampden-Sydney and the school's active LES chapter was Francis Schaeffer, a fearless evangelical Presbyterian thinker (Duriez 2008, p. 28). Schaeffer would later energetically combat secular ideologies and liberal doctrine in ways different from, but somewhat reminiscent of, Eggleston.

\section{Conclusion}

In January 1935 one LES leader reported that "there is one perilous pitfall which constantly besets the evangelical student. This is the pitfall of anti-intellectualism" (Cummings 1935, p. 5). In the face of evangelical intellectual irresponsibility, the LES was an important effort in trying to create and strengthen the evangelical mind. What the LES's actions reveal is that evangelical viewpoints were being transmitted to a number of the nation's colleges, universities, and seminaries. The LES may have had limited strength and influence. Yet, the saga of the LES reveals that secularization and liberal theology were not the only story. The history of the LES highlights Pan-Presbyterian dissent from theological liberalism and efforts to work together among Presbyterians. Xenia Seminary and its graduates' contributions to the LES indicate that this UP seminary deserves a somewhat more prominent place in the history of Presbyterianism and evangelicalism. In fact, it could be argued that there was a Princeton-Xenia conservative alliance most notably seen in the formation and subsequent mission of the LES. ${ }^{8}$ However, when Xenia joined with Pittsburgh seminary in 1929 and when Machen moved his forces out of Princeton in that same year the alliance was in trouble. The death of Kyle in 1933 and Machen in 1937 also seemed to deprive the LES of its two most notable visionary leaders. The death of 
LES leader Leander Keyser, a senior Lutheran theologian from Hamma Divinity School in Ohio, in 1937 was also a blow. By the end of the 1930s the LES had lost many of its most highly decorated scholars. The last edition of The Evangelical Student in 1939 featured an essay from up-and-coming Presbyterian New Testament scholar Everett F. Harrison and a book review from an unknown Canadian Presbyterian student named W. Stanford Reid. Both Harrison, who later taught at Fuller Seminary, and Reid, who later taught at McGill and Guelph universities, would go on to play key roles in the resurgence of evangelical scholarship. The success of Inter-Varsity's work in the early 1940s seems to have sapped LES efforts, and by 1943 the LES ceased operations. However, the explosive growth of evangelical student ministries in the twentieth century indicates that the LES vision was in some ways realized. Machen was a strategic thinker, and his ideas persisted in the students and scholars he influenced in the LES, and lives were changed. Machen was a confessional Presbyterian conservative, but his efforts in the LES also reveal him to be an ecumenical evangelical Presbyterian and one of the most consequential Christian scholars of the 20th century. Likewise, Kyle's involvement in the LES also shows another avenue of influence in his important but neglected career. The evidence indicates that Kyle deserves a more prominent place in the history of evangelical scholarship, but also in the history of archaeological research. The fact that so many of evangelicalism's most prominent scholars emerged from the LES is an important finding of this paper. The convergence of the populist oriented United Presbyterian tradition as exemplified by Kyle combined with the efforts of Machen and the professors of Old Princeton in the LES reveal an important way Presbyterians worked together to oppose theological liberalism and advance evangelical scholarship into the future.

Funding: This research received no external funding.

Institutional Review Board Statement: Not applicable.

Informed Consent Statement: Not applicable.

Data Availability Statement: Not applicable.

Conflicts of Interest: The author declares no conflict of interest.

\section{Notes}

On McPheeters (Lucas 2015, For a Continuing Church).

2 Kyle's words in Wheaton College Archaeology brochure quoted by Timothy Larsen in, "Joseph P. Free and the Romance of Biblical Archaeology," John Monson and Daniel Master eds., Dothan I, p. 5.

3 Additionally, David P. Livingston, a 1954 graduate of Pitt-Xenia, founded Associates for Biblical Research, a more conservative evangelical biblical archaeology organization.

4 Charles Woodbridge quoted by John Woodbridge in the "Fundamentalist-Modernist Controversy," Dirk R. Buursma, Katya Covrett, and Verlyn D. Vergbrugge eds., Evangelical Scholarship, Retrospects, and Prospects. Grand Rapids: Zondervan, 2017, p. 75.

5 The Evangelical Student. January 1933, p. 1; The Evangelical Student. January 1939, inside back cover.

6 "Report of Committee on Sterling College" Minutes of the Synod of Kansas, 1933, p. 23. quoted in Daniel T. Julich (2018), "Bulwork of Democracy: Optimism and Identity at Sterling College in the War Years," unpublished paper, p. 2.

$7 \quad$ Clare Cox quoting Edward F. Overton, Virginia Tech Magazine. Winter 2008. In Retrospect (Cox 2008). See also Edward F. Overton. A Study of the Life and Work of Joseph Dupey Eggleston, Junior (Ph.D. diss., University of Virginia, 1943).

8 One LES founder, P.B. Fitzwater, who served as professor of theology at Moody was a graduate of both Princeton and Xenia seminaries.

\section{References}

Albright, William Foxwell. 1933. In Memoriam, Melvin G. Kyle. In Bulletin of the American Schools of Oriental Research. Chicago: The University of Chicago Press, pp. 5-6.

Barton, George. 1913. Higher Archaeology and the Verdict of Criticism. Journal of Biblical Literature 32: 244-60. [CrossRef]

Boggs, John J. 1935. Two Religions. The Evangelical Student, October. 20-25.

Buswell, James Oliver. 1962. A Systematic Theology of the Christian Religion. Grand Rapids: Zondervan. 
Cox, Clare. 2008. In Retrospect. Virginia Tech Magazine. Available online: https:/ /www.vtmag.vt.edu/fall08/retrospect.html (accessed on 16 June 2021).

Cummings, Calvin Knox. 1932. What the League Has Meant to Me. The Evangelical Student, January. vol. VI, 17.

Cummings, Calvin Knox. 1935. The Peril of the Evangelical Student. The Evangelical Student, January. 5.

Cummings, Calvin Knox. 1937. Editorials: Dr. J. Gresham Machen and the League of Evangelical Students. The Evangelical Student, April. vol. XII, 1-2.

Davis, Moshe. 1995. Melvin Grove Kyle. In America and the Holy Land. Westport: Praeger, p. 171.

Duriez, Colin. 2008. Francis Schaeffer: An Authentic Life. Wheaton: Crossway.

Eggleston, J. D. 1937. The Search for Truth: Where is it Leading. The Evangelical Student, October. 5-14.

Gilliland, Thomas Matthew. 2008. Truth and Love: The United Presbyterian Church of North America-a Fifty Year Retrospective. Maryville: United Presbyterian Conservancy of North America, pp. 285-86.

Glass, William R. 2001. Strangers in Zion. Macon: Mercer University Press, p. 147.

Hall, H. R. 1927. Édouard Naville. The Journal of Egyptian Archaeology 13: 4. [CrossRef]

Hertz, Todd. 2002. Influential Teacher and Leader Kenneth Kantzer Dies. Christianity Today. Available online: https://www. christianitytoday.com/ct/2002/juneweb-only/6-24-31.0.html (accessed on 15 October 2018).

Hunt, Mary. 1932. Kept by The Power of God. The Evangelical Student, January. 18-19.

Hunt, Gladys. 1991. For Christ and the University: The Story of InterVarsity Christian Fellowship in the USA, 1940-1990. Downers Grove: InterVarsity Press.

Julich, Daniel. 2018. Bulwark of Democracy: Optimism and Identity at Sterling College. unpublished paper. 1-24.

Keillor, Steven. 2008. Basis of Belief: A Century of Debate and Drama at the University of Minnesota. Lakeville: Pogo Press.

Kelsey, Hugh. 1931. Enrichment of the Spiritual Life. The Evangelical Student, January. 5-9.

Kelsey, Hugh. 1937. The Christian College as a Spiritual Force. Christian Education 20: 337-42.

Kelsey, Hugh. 2007. Garden Variety Preacher. Sterling: Sterling College.

Kyle, Melvin Grove. 1905. Egyptian Sacrifices: A Study of Scenes in Painting and In Sculpture. Paris: Librairie of Emile Bouillon.

Kyle, Melvin Grove. 1907. McNary Family with Trees and History. Pittsburgh: McNary \& Simpson, Printers, p. 130.

Kyle, Melvin Grove. 1908. Archaeological Department: Notes from the Field. The Bible Champion, March. 197.

Kyle, Melvin Grove. 1912. The Deciding Voice of the Monuments in Biblical Criticism. Oberlin: Bibliotecha Sacra Company.

Kyle, Melvin Grove. 1917. The Bible in the Light of Archaeological Discoveries. Bibliotheca Sacra 74: 1-19.

Kyle, Melvin Grove. 1926. The Story of Ancient Sodom in Light of Modern Science. The Evangelical Student, vol. 1, 10-12.

Kyle, Melvin Grove. 1932. If the Foundations Be Destroyed, What Can the Righteous Do? The Evangelical Student, vol. VI, 26-28.

Lapp, Nancy. 1994. Archaeology and the James L. Kelso Bible Lands Museum. In Ever a Frontier. Edited by James Arthur Walther. Grand Rapids: Eerdmans, pp. 237-62.

Larsen, Thomas. 1998. The Company of Preachers. Grand Rapids: Kregal Publications.

Larsen, Timothy. 2005. Joseph P. Free and the Romance of Biblical Archaeology. In Dothan I. Edited by John Monson and Daniel Master. Winona Lake: Eisenbrauns, pp. 1-6.

Leonard, John William. 1908. Kyle, Melvin Grove. In Who's Who in Pennsylvania. New York: L.R. Hamersly and Co., p. 418.

Lucas, Sean Michael. 2015. For a Continuing Church. Philipsburg: P\&R Publishing.

Machen, J. Gresham. 1923. Christianity and Liberalism. New York: The MacMillan Company.

McEwan, William. 1906. Address Introductory to that By President Hall. The Bible Champion, June. 439.

Mueller, J.T. 1926. The Theological Observer. Theological Monthly, July. vol. vi, 204.

Orr, James. 1914. The Problem of the Old Testament. New York: Charles Scribner's Son.

Orr, James. 1930. Preface. In International Standard Bible Encyclopedia. Chicago: The Howard-Severance Company.

Price, James. 1905. The History of Seventh United Presbyterian Church, Frankford, Philadelphia. Philadelphia: Privately Published.

Robinson, George L. 1920. Review of Moses and the Monuments. Bibliotecha Sacra 77: 345.

Running, Leona Glidden, and David Noel Freedman. 1975. William Foxwell Albright. New York: Two Continents Publishing Group, LTD.

Scorgie, Glen G. 1988. A Call for Continuity: The Theological Contribution of James Orr. Macon: Mercer University Press.

Townsend, L. T. 1913. Where are the Straight Books? The Bible Champion, September. 93.

Whitelaw, Thomas. 1903. Old Testament Critics. London: Kegan Paul, Trench, Trubner and Co.

Woodbridge, John. 2017. Fundamentalist-Modernist Controversy. In Evangelical Scholarship, Retrospects, and Prospects. Edited by Dirk R. Buursma, Katya Covrett and Verlyn D. Vergbrugge. Grand Rapids: Zondervan Academic, pp. 57-107.

Wright, G. Fredrick. 1916. The Story of My Life and Work. Oberlin: Bibliotecha Sacra Company. 